\title{
EDitorial V. 26, N. 3
}

http://dx.doi.org/10.1590/1984-0292/1379

Este é o volume 26.3 de Fractal: Revista de Psicologia. Com o volume atual, encerramos nossas atividades de 2014. Comprometida com uma política de publicização de conhecimento relevante no campo de estudos da subjetividade, nossa Revista encerra o ano de 2014, destacando o importante fomento à editoração de periódicos da FAPERJ, o que garantiu a manutenção de nossa rotina e a possibilidade de se adequar às novas exigências editoriais para os periódicos em ciências humanas e sociais em nosso país.

Temos projetos para 2015. Esperamos que o próximo ano seja cenário de multiplicação de perspectivas em torno da produção e divulgação de conhecimento em ciências humanas e sociais, sem a submissão a critérios puramente quantitativos e mercadológicos, com o devido apreço pelas especificidades dos problemas emergentes em nosso contexto social e político. No próximo ano, também estaremos presentes na defesa de periódicos que se coadunem com políticas de formação de leitores e de divulgação do trabalho de pesquisadores em ciências humanas e sociais envolvidos com o campo de estudos da subjetividade.

Convidamos nossos leitores a compartilharem conosco as indagações teóricas em jogo nos artigos ora apresentados. Um ótimo ano de 2015 para todos nós.

\section{Marcelo Santana Ferreira}

Editor de Fractal: Revista de Psicologia. 